\title{
Effects of oestrone sulphate, oestradiol and progesterone on protein sulphation in the guinea-pig uterus*
}

\author{
M. C. Thiard, M. Nicollier, A. Mahfoudi and G. L. Adessi \\ Unité de Recherche de Biochimie Hormonale et des Régulations, INSERM, Besançon, France
}

\begin{abstract}
Summary. Ovariectomized guinea-pigs were treated with oestradiol-17 $\beta\left(E_{2}\right)$, oestrone sulphate $\left(E_{1} S\right)$ and progesterone $(P)$ and the in-vitro incorporation of ${ }^{35} \mathrm{SO}_{4}$ was studied in uterine fragments. The net uptake of ${ }^{35} \mathrm{SO}_{4}$ into tissue was only increased by oestradiol-17 $\beta$ plus progesterone. The incorporation of ${ }^{35} \mathrm{SO}_{4}$ in the tissue-associated proteins was increased after treatment with $\mathrm{E}_{2}$ and $\mathrm{E}_{1} \mathrm{~S}$ compared with untreated controls (3.1- and 2.5-fold, respectively). For secreted proteins, all hormone treatments induced an increase in protein sulphation, the highest increase occurring when progesterone was administered after oestrogens. Tyrosine ${ }^{35} \mathrm{SO}_{4}$ was identified in protein extracts from tissues and media and values were greater after hormone treatments. The biggest increase in tyrosine ${ }^{35} \mathrm{SO}_{4}$ was observed in secreted proteins in the $\mathrm{E}_{1} \mathrm{~S}+\mathrm{P}$ treatment group.

The patterns of ${ }^{35} \mathrm{~S}$-sulphate-labelled proteins were examined by SDS-polyacrylamide gel electrophoresis. In tissue extracts, the most striking differences related to the hormone treatments were observed in the $M_{\mathrm{r}} 94000-190000$ region. A sulphated protein band of $M_{\mathrm{r}} 102000$ was specifically found in the $\mathrm{E}_{2}+\mathrm{P}$ group and a band of $M_{\mathrm{r}} 125000$ only in the $\mathrm{E}_{1} \mathrm{~S}+\mathrm{P}$ group. The $M_{\mathrm{r}} 125000$ band was also found in tissue proteins from the $\mathrm{E}_{1} \mathrm{~S}+\mathrm{P}$-treated animals after the incorporation of ${ }^{35} \mathrm{SO}_{4}$ in vivo. This protein band may be a marker of the action of oestrone sulphate plus progesterone. For secreted proteins, those with a molecular weight $>100000$ were more abundant in the oestrogen plus progesterone-treated groups than in the oestrogentreated groups. The content of tyrosine sulphate in each protein band ranged from 8 to $25 \%$ of the total radioactivity. No protein sulphated exclusively on the tyrosine residues was found.

These studies provide the first description of the effects of steroid hormones on sulphated proteins in the guinea-pig uterus and suggest that oestrone sulphate is a potent biologically active hormone in the uterus.
\end{abstract}

Keywords: guinea-pig; protein; sulphation; uterus; hormones

\section{Introduction}

Oestrone sulphate has been described for various species as a prehormone which releases unconjugated oestrogens into target tissues and especially into the uterus after hydrolysis by oestrone sulphatase (Tseng et al., 1972; Rossier \& Pierrepoint, 1974; Adessi et al., 1982; Pasqualini et al., 1982; Moutaouakkil et al., 1984). However, a part of the oestrone sulphate entering the target tissue remains as sulphoconjugate (Adessi et al., 1982). In vivo, oestrone sulphate is a potent oestrogen inducing a uterotrophic effect and an increase of uterine progesterone receptors in ovariectomized guinea-pigs (Moutaouakkil et al., 1984). Oestrone sulphate could, therefore, also

*Reprint requests to Dr M. Nicollier, INSERM U 198, 240 route de Dole, 25000 Besançon, France. 
have a direct effect on protein synthesis. Brooks et al. (1969) reported a direct effect of oestrone sulphate on protein synthesis in microsomal supernatants isolated from the uterus of both rat and rabbit. This effect was not found with unconjugated oestrone and oestradiol-17ß. Alkhalaf et al. $(1987 \mathrm{a}, \mathrm{b})$ have demonstrated a specific effect of this sulphoconjugated oestrogen on the surface of the endometrial cells, mimicking a secretory aspect.

Oestrogens induce the synthesis of specific proteins in target tissues. Oestradiol-17 $\beta$, the most potent biological oestrogen, also increases the biosynthesis of glycoproteins (Joshi \& Ebert, 1976; Takata \& Terayama, 1977; Dutt et al., 1986) and in particular sulphated glycoproteins (Takata \& Terayama, 1979; Isemura et al., 1981) in the uterus. Protein sulphation both on carbohydrate moieties and tyrosine residues is a post-translational modification frequently observed in secretory glycoproteins, peptides and peptide hormones (Palade, 1975; Frazier \& Glaser, 1979; Green et al., 1984; Hille et al., 1984). Huttner \& Baeuerle (1988) have concluded that tyrosine sulphation is an irreversible post-translational modification of secretory proteins and, therefore, results in a life-long alteration in the phenotype of these proteins. Tyrosine sulphation and tyrosylprotein sulphotransferase activity have not been reported in the uterus. A better understanding of the biochemistry of uterine secretions is important because sperm migration and blastocyst transport to the site of implantation take place in this fluid. For these reasons, we undertook to determine the effect of oestradiol-17 $\beta$, oestrone sulphate and progesterone on the in-vitro sulphation of tissue-associated and secreted proteins in guinea-pig uterus.

\section{Materials and Methods}

\section{Materials}

Guinea-pigs of the Hartley albino variety were purchased from the Centre de Zootechnie Coblanbel (Montmedy, France). Tissue culture basal Medium Eagle (BME) without sulphate and supplies were obtained from Flow Laboratories (Puteaux, France). Oestrone sulphate, oestradiol-17ß, and progesterone were from Sigma Chimie (La Verpillière, France), ${ }^{35} \mathrm{SO}_{4}$ (sp. act. $25-40 \mathrm{Ci} / \mathrm{mg}$ ) from Amersham (Les Ulis, France) and pronase (Streptococcus griseus), $7000 \mathrm{U} / \mathrm{g}$, was purchased from Boerhinger (Mannheim, FRG). All chemicals for the electrophoretic analysis were purchased from Serva (Heidelberg, FRG). All chemicals were of the analytical reagent grade.

\section{Animal treatments and uterus preparation}

Mature guinea-pigs (10-12 weeks old, about $700 \mathrm{~g}$ ) were bilaterally ovariectomized on the 2 nd day after vaginal opening. They were allowed to recover for at least 20 days. Ovariectomized guinea-pigs maintained on a $12-\mathrm{h}$ light:12-h dark cycle were divided into 5 groups: (1) untreated; (2) oestradiol-17 7 -treated; (3) oestradiol-17 $\beta$ plus progesterone-treated; (4) oestrone sulphate-treated; (5) oestrone sulphate plus progesterone-treated. Hormone injection schedules were as follows: Groups 2 and 3 received a s.c. priming oestrogen injection of $10 \mu \mathrm{g}$ oestradiol-17 $\beta$ and Groups 4 and 5 received $10 \mu \mathrm{g}$ oestrone sulphate in $1 \mathrm{ml}$ ethanol-saline $(1: 9 \mathrm{v} / \mathrm{v}$. saline $=0 \cdot 15 \mathrm{M}-\mathrm{NaCl})$ on each of 3 consecutive days. At $16 \mathrm{~h}$ after the final priming oestrogen injection, Groups 3 and 5 received a s.c. hormone injection of $10 \mu \mathrm{g}$ progesterone in $1 \mathrm{ml}$ ethanol-saline $(1: 9 \mathrm{v} / \mathrm{v})$. Groups 2 and 4 received vehicle alone. Group 1 (untreated control group) received corresponding injections of vehicle alone.

The animals were killed by decapitation $8 \mathrm{~h}$ after the last injection and uteri were excised, stripped free of fat and mesentery. Cervices were excised and uteri were diced with a razor blade in Medium BME at $4^{\circ} \mathrm{C}$. The diced tissues were then washed 3 times with $4 \mathrm{ml}$ Medium BME.

\section{Metabolic labelling of tissues}

Fragments of organs $\left(0.30 \mathrm{~g}\right.$ per assay) were incubated at $37^{\circ} \mathrm{C}$ in an humidified atmosphere of air- $\mathrm{CO}_{2}$ at a ratio of $95: 5$ for $6-18 \mathrm{~h}$, with ${ }^{35} \mathrm{SO}_{4}$ (sp. act. $\left.0.5 \mathrm{mCi} / \mathrm{ml}\right)$ and the corresponding hormones $(1 \mathrm{nmol}$ oestradiol-17 $7 / 1$, $0 \cdot 1 \mu \mathrm{mol}$ oestrone sulphate $/ \mathrm{l}$ or $10 \mathrm{nmol}$ progesterone $/ \mathrm{l}$ ) in $4 \mathrm{ml}$ Medium BME without sulphate, modified as follows: $9.34 \mathrm{mg} \mathrm{BME} / \mathrm{ml}, 1.85 \mathrm{mg} \mathrm{NaHCO} / \mathrm{ml}, 10 \mathrm{mmol}$ L-glutamine $/ 1), 100 \mathrm{U}$ penicillin $/ \mathrm{ml}, 100 \mu \mathrm{g}$ streptomycin $/ \mathrm{ml}$, $20 \mathrm{mmol} \mathrm{Hepes} / 1), 5 \mu \mathrm{g}$ insulin/ml $(\mathrm{pH} 7 \cdot 4)$. At the end of the incubation period, the tissue fragments were washed several times with modified Medium BME, plus $0.2 \mathrm{mg} \mathrm{MgSO} \cdot 7 \mathrm{H}_{2} \mathrm{O} / \mathrm{ml}$, and tissues and media were prepared for analysis. 


\section{Tissue and medium preparation}

Tissues were frozen in liquid nitrogen, crushed with a ThermoVac crusher and homogenized at $4^{\circ} \mathrm{C}$ with a Potter-Elvehjem homogenizer in sample buffer (Laemmli, 1970). Homogenates were boiled for $5 \mathrm{~min}$, cleaned by centrifugation at $9000 \mathrm{~g}$ for $20 \mathrm{~min}$ and supernatants kept at $-80^{\circ} \mathrm{C}$. Media were centrifuged for $15 \mathrm{~min}$ at $160 \mathrm{~g}$ at $4^{\circ} \mathrm{C}$. Supernatants were boiled for 4 min then precipitated with 5 volumes of acetone at $-20^{\circ} \mathrm{C}$ for $16 \mathrm{~h}$. After centrifugation at $9000 \mathrm{~g}$ for $10 \mathrm{~min}$, pellets were solubilized in sample buffer and stored at $-80^{\circ} \mathrm{C}$.

\section{Analytical procedures}

Protein concentration was determined by the technique of Lowry et al. (1951) modified by Tan (1978) using BSA as standard.

Determination of sulphate uptake. Aliquants of the solubilized uterine samples were used for the determination of radioactivity by liquid scintillation counting and protein content. Sulphate uptake was expressed as a ratio of ${ }^{35} \mathrm{SO}_{4}$ to total proteins ( $\mathrm{cpm} / \mathrm{mg}$ protein).

Incorporation of ${ }^{35} \mathrm{SO}_{4}$. Tissue or medium extracts were diluted $2 \cdot 5$-fold with sample buffer containing $0.2 \mathrm{mg}$ $\mathrm{MgSO}_{4} \cdot 7 \mathrm{H}_{2} \mathrm{O} / \mathrm{ml}$ and then precipitated with 5 volumes of acetone at $-20^{\circ} \mathrm{C}$ for $16 \mathrm{~h}$. After centrifugation at $9000 \mathrm{~g}$, pellets were washed 4 times with $80 \%$ acetone. Protein content and ${ }^{35} \mathrm{SO}_{4}$ were determined in the solubilized pellets. The ratio of ${ }^{35} \mathrm{SO}_{4}$ to total proteins (c.p.m./mg protein) was used to express sulphate incorporation into proteins.

Polyacrylamide gel electrophoresis. Aliquants of tissue and medium extracts $(200 \mu \mathrm{g}$ protein) were subjected to sodium dodecyl sulphate-polyacrylamide gel electrophoresis (SDS-PAGE) (Laemmli, 1970), in 4-22\% gradient polyacrylamide gels. After electrophoresis, gels were stained with Coomassie blue and fluorographed (Chamberlain, 1979). For radioactivity counting, they were cut into 90 equal sections $(2 \mathrm{~mm}$ wide). Sulphated proteins were eluted from the polyacrylamide gels after extensive digestion of the gel sections with $1 \mathrm{ml}$ pronase solution $(50 \mu \mathrm{g} / \mathrm{ml})$ (Huttner, 1984) and radioactivity was measured by liquid scintillation counting.

Analysis of tyrosine-o- ${ }^{35} \mathrm{SO}_{3}$. Protein-bound tyrosine- ${ }^{-}{ }^{35} \mathrm{SO}_{4}$ was determined in the tissue-associated and medium extracts before or after electrophoretic separation according to the method of Huttner (1984). Briefly, fractions eluted from the gels by pronase digestion or fractions precipitated by acetone were hydrolysed with $\mathrm{Ba}(\mathrm{OH})_{2}$ $(0.2 \mathrm{~mol} / \mathrm{l})$ at $110^{\circ} \mathrm{C}$ for $24 \mathrm{~h}$. After centrifugation at $9000 \mathrm{~g}$, at $4^{\circ} \mathrm{C}$, supernatants were neutralized with sulphuric acid and centrifuged as above. Tyrosine- $-{ }^{-35} \mathrm{SO}_{4}$ was measured using reverse-phase high-performance liquid chromatography (RPHPLC).

RPHPLC analysis. Neutralized supernatants containing $3 \mu \mathrm{l}$ tyrosine- $o$-sulphate standard solution $(2 \cdot 5 \mu \mathrm{mol} / \mathrm{ml})$ were lyophilized, dissolved in $20 \mu \mathrm{l}$ water and purified by acetone precipitation as described by Huttner (1984). After centrifugation, supernatants were collected and evaporated. Residues were dissolved in water $(10 \mu l)$ and derivatized by adding 2 volumes of a solution composed of $o$-phthaldialdehyde $(0.745 \mathrm{~mol} / \mathrm{l})$ in ethanol $(50 \mu \mathrm{l})$, $\beta$-mercaptoethanol $(6 \mu \mathrm{l}), 10 \mathrm{mg}$ Brij/ $/ \mathrm{ml}(25 \mu \mathrm{l})$ and $1 \cdot 25 \mu \mathrm{l}$ sodium phosphate buffer $(0 \cdot 5 \mathrm{~mol} / \mathrm{l} ; \mathrm{pH} 10 \cdot 3)$. The fluorescence reaction was allowed to proceed for $1 \mathrm{~min}$ before injecting samples $(15 \mu \mathrm{l})$ onto a reverse-phase $(5 \mathrm{~mm} \times 10 \mathrm{~cm})$ column (Novapak C18, Waters, Les Ulis, France). Amino acids were eluted using a linear gradient with a double slope of triethylamine-acetic acid $(0.01875 \mathrm{~mol} / \mathrm{l} ; \mathrm{pH} \mathrm{7.5)}$ (Solvent A) and acetonitrile (Solvent B) as described by Larsen \& West (1981), modified as follows: $10 \mathrm{~min}$ in Solvent A then from 0 to $27 \%$ Solvent B for $35 \mathrm{~min}$, then from 27 to $70 \%$ Solvent B for $10 \mathrm{~min}$. The elution profile was monitored with an on-line spectrophotometer at $340 \mathrm{~nm}$ and a computer (Intersmat Instruments, Courtry, France). Column eluates were collected in fractions of $2 \mathrm{ml}$ for liquid scintillation counting and quantification of ${ }^{35} \mathrm{SO}_{4}$ in amino acids. The retention time of fluorescent derivatives was compared to that of similarly derivatized tyrosine-o-sulphate standard synthesized as described by Dogson $e t$ al. (1959), injected alone or with a $2.5 \mu \mathrm{mol} / \mathrm{ml}$ standard solution of amino acids (Sigma Chimie, La Verpillière, France).

\section{Statistical method}

Statistical differences were analysed using a one-way analysis of variance with multiple comparison test and Mann-Whitney U-test. Significance is taken as $P<0.05$.

\section{Results}

\section{Sulphate incorporation into total tissue-associated and secreted proteins}

The ratio of incorporation of ${ }^{35} \mathrm{SO}_{4}$ to total tissue-associated or secreted proteins was increased in the hormone-treated groups compared with the untreated control group (Fig. 1). In the tissueassociated proteins, the increase in sulphate incorporation appeared after a lag period of $12 \mathrm{~h}$, 
whereas in the secreted proteins the increase in protein sulphation was detectable after $6 \mathrm{~h}$ of incubation and the highest values were obtained in Groups 3 and 5 after $18 \mathrm{~h}$ of incubation. Specific cellular proteins, actin $\left(M_{\mathrm{r}} 45000\right.$, isoelectric point (pI) 5.40-5.44), $\alpha$ and $\beta$ tubulin ( $M_{\mathrm{r}} 55000$ and 65000 , pI 5.20), were identified by 2-dimensional SDS-PAGE as described by Chaminadas et al. (1989) in the cellular lysates, but were undetectable in the medium preparations. On this basis, cell lysis was not detectable during the 18 -h incubation period with ${ }^{35} \mathrm{SO}_{4}$. Consequently, all the other incubations carried out during this study were maintained for $18 \mathrm{~h}$.

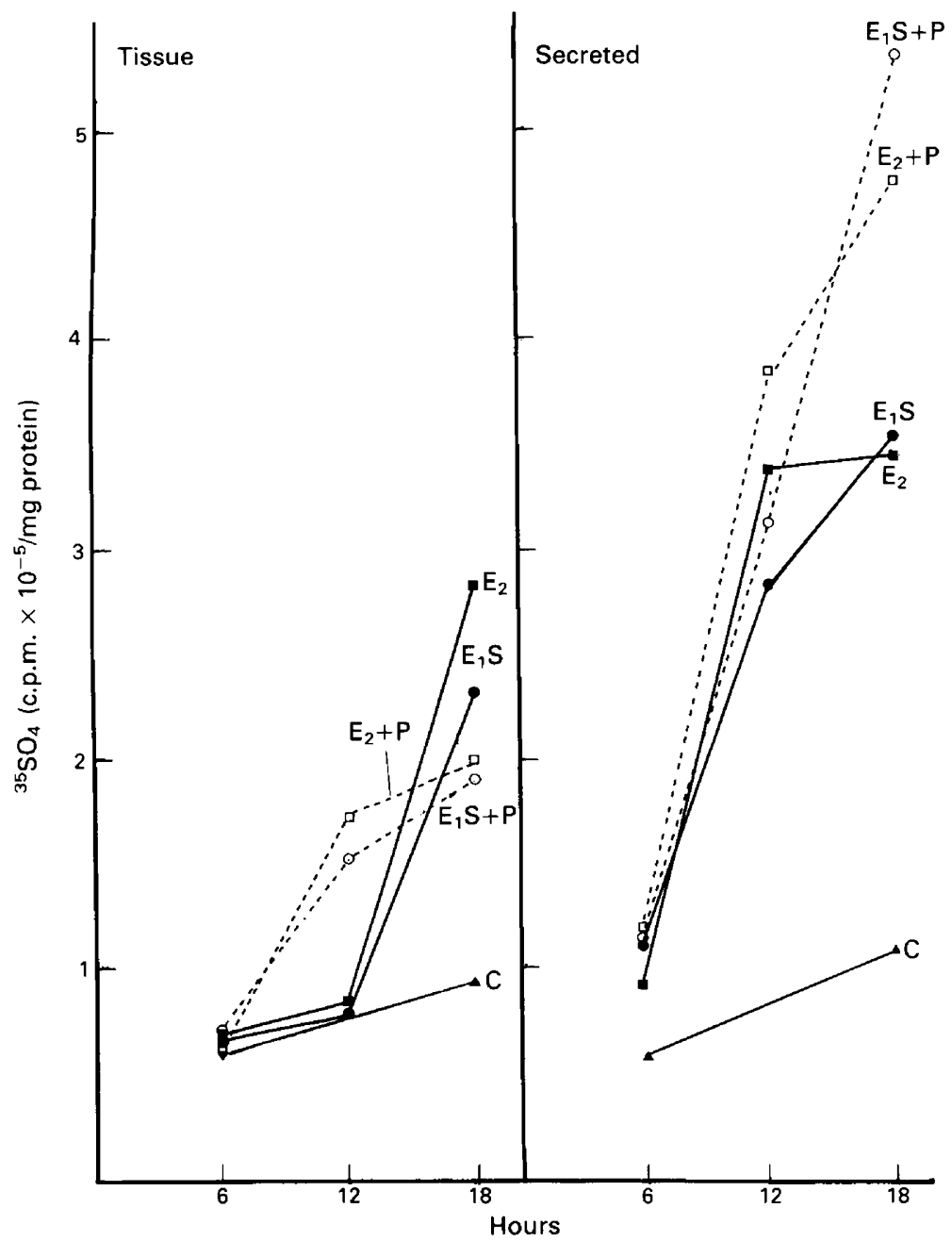

Fig. 1. Time course of incorporation of ${ }^{35} \mathrm{SO}_{4}$ into total uterine proteins. Ovariectomized guinea-pigs were treated with oestradiol-17 $\beta\left(E_{2}\right.$, Group 2$)$, oestrone sulphate $\left(E_{1} S\right.$, Group 4$)$, alone or associated with progesterone $\left(E_{2}+P\right.$, Group 3; $E_{1} S+P$, Group 5). Untreated control animals (C, Group 1) received vehicle alone. Uterine fragments were incubated with ${ }^{35} \mathrm{SO}_{4}$ for 6-18 h. Each point is the mean of 3 independent determinations.

Table 1 sets out the values of the uptake of sulphate into tissue and sulphate incorporation into proteins measured after $18 \mathrm{~h}$ of incubation. The total protein content of incubated tissues or media did not vary significantly $(P>0.05)$ according to the hormone treatments. Consequently, the results were expressed per $\mathrm{mg}$ total protein. The uptake of ${ }^{35} \mathrm{SO}_{4}$ into tissue was significantly 
increased (1-4-fold) in Group 3 compared with Group 1. No significant variations were noted for the other treated groups. The incorporation of ${ }^{35} \mathrm{SO}_{4}$ into the tissue-associated proteins was significantly increased in Groups 2 and 4, compared with Group 1, 3.1- and 2.5-fold, respectively. No significant variations were observed in Groups 3 and 5. Variance analysis of the secreted proteins revealed that hormone treatment induced a significant increase in protein sulphation. In Groups 3 and 5 , the incorporation of $\left[{ }^{35} \mathrm{~S}\right]$ sulphate into the secreted proteins was higher than in Groups 2 and 4 (1-4- and 1·5-fold, respectively).

Table 1. Uptake into tissue and incorporation into tissue-associated and secreted proteins of ${ }^{35} \mathrm{SO}_{4}$ after incubation for $18 \mathrm{~h}$ of guinea-pig uterine fragments

\begin{tabular}{|c|c|c|c|c|c|}
\hline \multirow[b]{2}{*}{$\begin{array}{c}\text { Groups } \\
\text { (treatments) }\end{array}$} & \multicolumn{3}{|c|}{ Tissue } & \multicolumn{2}{|c|}{ Medium } \\
\hline & $\begin{array}{c}\text { Protein } \\
\text { (mg/g uterus) } \dagger\end{array}$ & $\begin{array}{c}\text { Uptake of } \\
{ }^{35} \mathrm{SO}_{4} \\
\text { (c.p.m. } \times 10^{-5} / \mathrm{mg} \\
\text { protein) }\end{array}$ & $\begin{array}{c}{ }^{35} \mathrm{SO}_{4} \\
\text { incorporation } \ddagger \\
\text { (c.p.m. } \times 10^{-5} / \mathrm{mg} \\
\text { protein) }\end{array}$ & $\begin{array}{c}\text { Protein } \\
\text { (mg/g uterus) } \dagger\end{array}$ & $\begin{array}{c}{ }^{35} \mathrm{SO}_{4} \\
\text { incorporation } \ddagger \\
\text { (c.p.m. } \times 10^{-5} / \mathrm{mg} \\
\text { protein) }\end{array}$ \\
\hline $\mathrm{I}(\mathrm{C})$ & $38 \cdot 50 \pm 3 \cdot 80$ & $51 \cdot 70 \pm 2 \cdot 67$ & $0.92 \pm 0.36$ & $4.04 \pm 1.50$ & $1 \cdot 10 \pm 0.17$ \\
\hline $2\left(E_{2}\right)$ & $37 \cdot 42 \pm 5 \cdot 80$ & $62 \cdot 34 \pm 8 \cdot 15$ & $2.81 \pm 0.51^{\mathrm{b}}$ & $5.48 \pm 1.90$ & $3.48 \pm 0.71^{\mathrm{b}}$ \\
\hline $3\left(E_{2}+P\right)$ & $36 \cdot 84 \pm 4 \cdot 10$ & $73 \cdot 56 \pm 2 \cdot 36^{a}$ & $1.98 \pm 0.22$ & $5.90 \pm 2.40$ & $4.76 \pm 0.62^{b, c}$ \\
\hline $4\left(E_{1} S\right)$ & $33 \cdot 41 \pm 5 \cdot 30$ & $61 \cdot 27 \pm 6 \cdot 19$ & $2.61 \pm 0.50^{b}$ & $4.60 \pm 0.70$ & $3.54 \pm 0.91^{\mathrm{b}}$ \\
\hline $5\left(E_{1} S+P\right)$ & $31 \cdot 10 \pm 4 \cdot 80$ & $58 \cdot 86 \pm 4 \cdot 23$ & $1.90 \pm 0.27$ & $7 \cdot 15 \pm 2 \cdot 60$ & $5 \cdot 33 \pm 0.26^{\mathbf{b}, d}$ \\
\hline
\end{tabular}

Values are mean \pm s.d. of triplicate determinations performed on uteri from at least 2 separate guinea-pigs.

†Expressed in relation to the wet weight of incubated uterine fragments determined gravimetrically.

$\Varangle$ Ratio of ${ }^{35} \mathrm{SO}_{4}$ incorporation to total proteins, after acetone precipitation.

${ }^{\mathrm{a}} P<0.05$ compared with Group 1 ' $^{\mathrm{b}} P<0.01$ compared with Group $1 ;{ }^{\circ} P<0.05$ compared with Group 2 ; ${ }^{\mathrm{d}} P<0.01$ compared with Group 4.

\section{Sulphate incorporation into tyrosine}

Because incorporation of ${ }^{35} \mathrm{SO}_{4}$ can take place in the carbohydrate moieties and tyrosine residues of proteins (Huttner, 1984), the distribution of tyrosine- $0 \cdot{ }^{35} \mathrm{SO}_{3}$ was examined in protein extracts from tissues and media. Incorporation of ${ }^{35} \mathrm{SO}_{4}$ into tyrosine was determined in acetone precipitated proteins after alkaline hydrolysis by RPHPLC analysis. Tyrosine- $0 \cdot{ }^{35} \mathrm{SO}_{3}$ was identified in all extracts studied, whatever the hormone treatment and no other sulphated amino acid was detected. The fraction of sulphate incorporated into tyrosine, expressed as the percentage of total incorporation before alkaline hydrolysis, ranged from 4.6 to $8.8 \%$ in the tissue-associated proteins and $5 \cdot 2$ to $8 \cdot 3 \%$ in the secreted proteins.

Tyrosine sulphate content in tissue and secreted proteins was increased in the hormone-treated groups (Fig. 2). Secreted proteins were constantly more sulphated than tissue proteins. A significant increase (1.6-fold; $P<0.05)$ in labelled tyrosine content of secreted proteins was observed in Group 3 compared with Group 2. No significant variations were observed between these two groups in the tissue-associated proteins. The same significant increase $(P<0.05)$ in tyrosine sulphate content in both types of proteins was observed in Groups 3 and 4. In Group 5, the tyrosine sulphate content was increased slightly in both tissue and secreted proteins as compared with Group $4(P<0.05)$.

\section{Electrophoretic patterns of tissue-associated and secreted ${ }^{35} S$-sulphated proteins}

It was important to investigate whether any modification in the sulphate incorporation reflected any changes in the electrophoretic pattern that might reveal a specific hormone action. The patterns of ${ }^{35} \mathrm{SO}_{4}$ incorporation into proteins after $18 \mathrm{~h}$ of incubation were studied in tissue and medium 


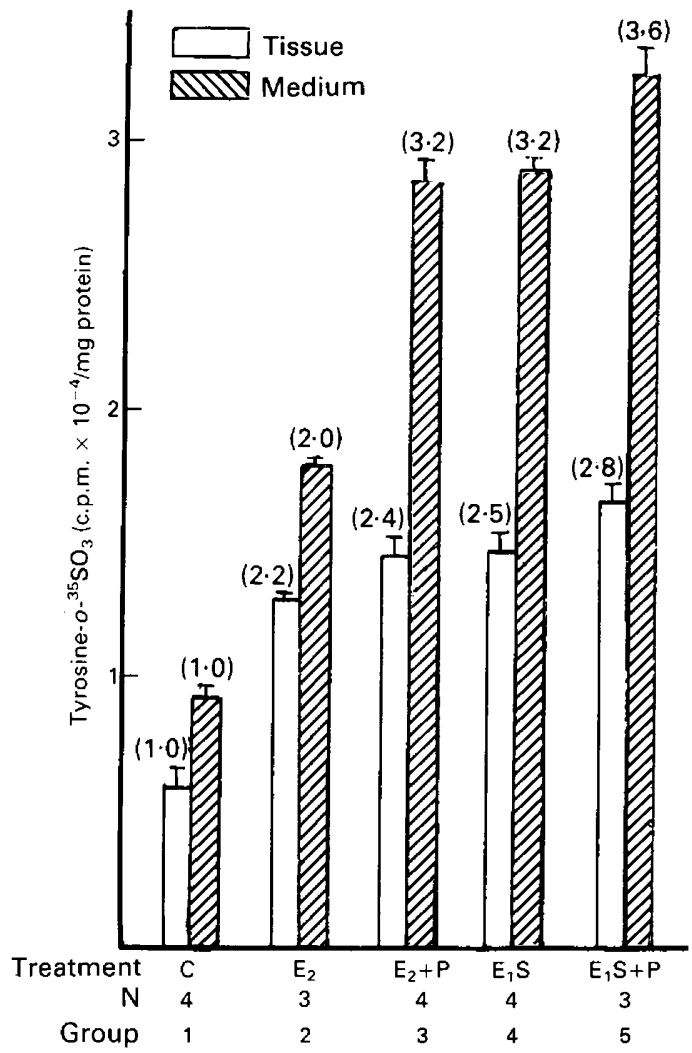

Fig. 2. Incorporation of ${ }^{35} \mathrm{SO}_{4}$ into tyrosine residues of tissue-associated proteins (open columns) and secreted proteins (hatched columns). Uterine fragments from untreated and hormone-treated guinea-pigs were incubated with ${ }^{35} \mathrm{SO}_{4}$ for $18 \mathrm{~h}$. Hormone treatments were as in Fig. 1. Values are mean \pm s.d. for the no. of animals indicated $(\mathrm{N})$. The numbers in parentheses give the fold increase compared to Group 1.

extracts by SDS-PAGE. After staining with Coomassie blue, no difference was observed in the protein patterns in relation to the hormone treatments (not shown). Fluorographs showed that sulphated proteins ran as a diffuse smear in the high $M_{\mathrm{r}}$ zone $(>94000)$; this was undoubtedly due to sulphated proteoglycans or glycosaminoglycans (Huttner, 1984). To circumvent this problem, incorporation of ${ }^{35} \mathrm{SO}_{4}$ into proteins was analysed in individual bands. After electrophoresis, the gels were sliced and the eluted fractions were evaluated for radioactivity as described in 'Materials and Methods'. The patterns of incorporation of ${ }^{35} \mathrm{SO}_{4}$ into proteins varied according to hormone treatments. Only concordant variations found in 3 independent experiments were retained and the results were analysed to reveal specific hormone actions.

Representative diagrams are shown in Fig. 3. In tissue extracts (Fig. 3a), the more striking differences between hormone-treated and untreated groups were located in the $M_{\mathrm{r}} 94000-190000$ range (Fig. 3a, inset). Two sulphated protein bands were found only in a specific hormone treatment: $M_{\mathrm{r}} 125000$ in Group 5 and $M_{\mathrm{r}} 102000$ in Group 3. The sulphated protein band $M_{\mathrm{r}} 112000$ was constantly found except in Group 2. Four sulphated protein bands incorporated more ${ }^{35} \mathrm{SO}_{4}$ after specific treatment: the block $\left(M_{\mathrm{r}} 165000-171000\right)$ in Group 2, $M_{\mathrm{r}} 131000$ in Group 4 and two low $M_{\mathrm{r}}$ sulphated protein bands (51000 and 64000$)$ in Group 5.

The interest of a sulphated protein of $M_{\mathrm{r}} 125000$ induced specifically by oestrone sulphate plus progesterone treatment led us to study in vivo the incorporation of ${ }^{35} \mathrm{SO}_{4}$ in guinea-pig uterine proteins. Guinea-pigs were untreated or treated with oestradiol-17 $\beta+$ progesterone or 


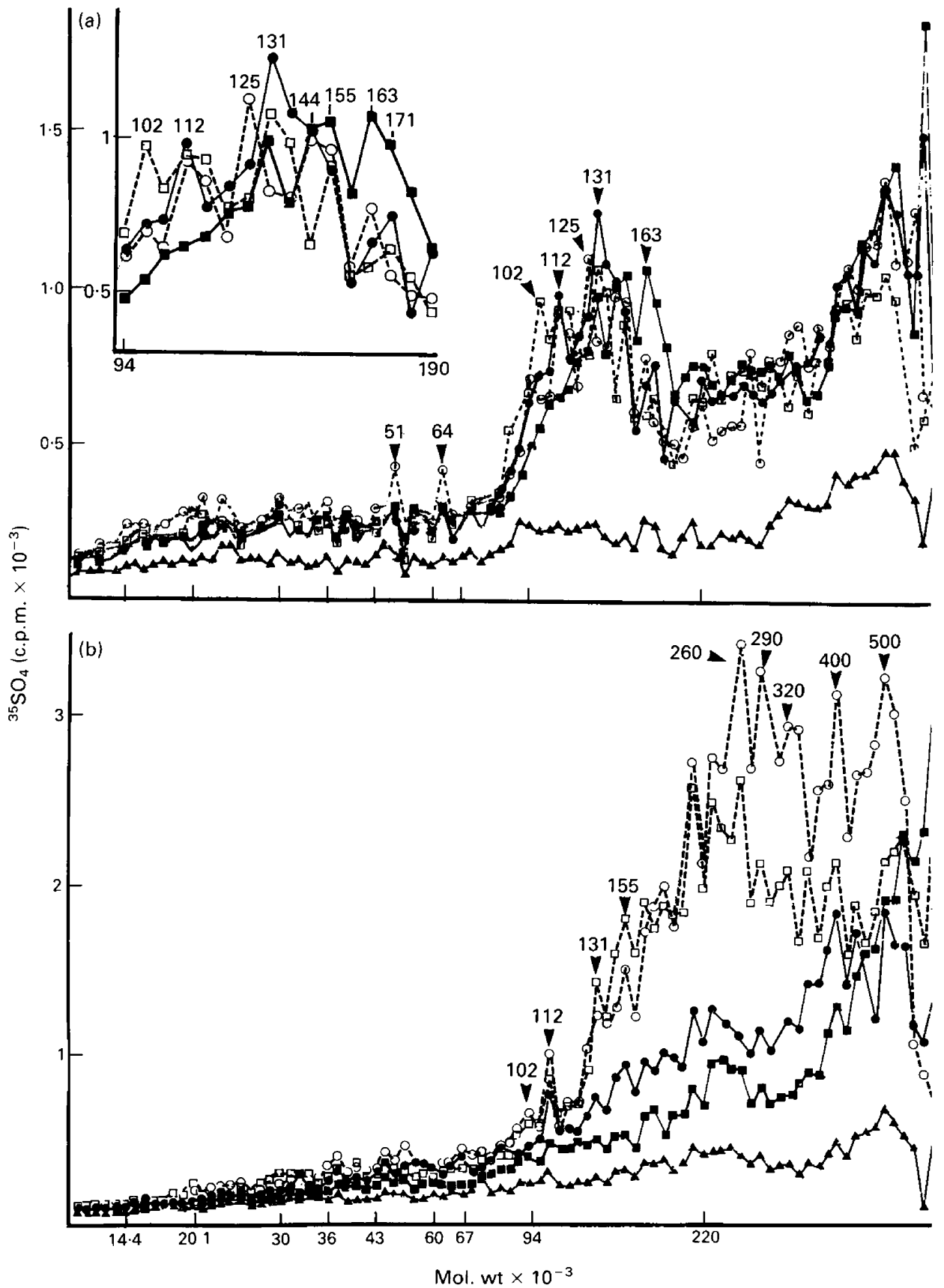

Fig. 3. Electrophoretic distribution of ${ }^{35} \mathrm{SO}_{4}$-labelled uterine proteins (a, tissue-associated proteins (inset: enlargement of the $M_{\mathrm{r}} 94000-190000$ region); b, secreted proteins) in 4-22\% SDSpolyacrylamide gels. Ovariectomized guinea-pigs were treated as in Fig. 1 (Group 1, $\mathbf{\Delta}-\mathbf{\Delta}$, control, Group 2, $\square-\square, E_{2}$, Group 3, $\square---\square, E_{2}+$ P, Group 4, - $-1, E_{1} S$, Group $\left.5, \mathrm{O}---\mathrm{O}, \mathrm{E}_{1} \mathrm{~S}+\mathrm{P}\right)$. Uterine fragments were incubated for $18 \mathrm{~h}$. The standards were: ferritin (half unit $\left.M_{\mathrm{r}} 220000\right)$, phosphorylase b $\left(M_{\mathrm{r}} 94000\right)$, albumin $\left(M_{\mathrm{r}} 67000\right)$, catalase $\left(M_{\mathrm{r}} 60000\right)$, ovalbumin $\left(M_{\mathrm{r}} 43000\right)$, lactate dehydrogenase $\left(M_{\mathrm{r}} 36000\right)$, carbonic anhydrase $\left(M_{\mathrm{r}} 30000\right)$, trypsin inhibitor $\left(M_{\mathrm{r}} 20100\right)$ and $\alpha$-lactalbumin $\left(M_{\mathrm{r}} 14400\right)$. Arrows indicate molecular weight $\left(\times 10^{-3}\right)$ of some characteristic sulphated protein bands. 
oestrone sulphate + progesterone as in 'Materials and Methods'. However, the final injection of progesterone was associated with ${ }^{35} \mathrm{SO}_{4}(15 \mathrm{mCi}$ per animal). Untreated animals were injected with vehicle alone. Animals were killed $24 \mathrm{~h}$ after the last injection. Uteri were immediately removed, washed in saline solution, cut into small pieces and prepared as described in 'Materials and Methods'. Uterine extracts were analysed using SDS-PAGE. After fluorography a radioactive zone located in the $M_{\mathrm{r}} 100000-130000$ region was markedly labelled in extracts from treated animals (data not shown). In this zone, two major regions may be distinguished. The first, ranging from $M_{\mathrm{r}} 100000$ to 120000 , displayed the same distribution of radioactivity in oestradiol$17 \beta+$ progesterone- and oestrone sulphate + progesterone-treated animals. The second $\left(M_{\mathrm{r}}\right.$ $120000-130000$ ) was more sulphated in oestrone sulphate + progesterone- than in oestradiol$17 \beta+$ progesterone-treated animals. The gel sections corresponding to the $M_{\mathrm{r}} 120000-130000$ region were hydrolysed with pronase and subjected to alkaline hydrolysis. The results showed that $70 \%$ of the incorporated ${ }^{35} \mathrm{SO}_{4}$ was hydrolysed and precipitated as $\mathrm{Ba}^{35} \mathrm{SO}_{4}$, suggesting that $70 \%$ of the sulphate was bound to the carbohydrate moieties (Huttner, 1984). In the remaining 30\%, tyrosine- $o-{ }^{35} \mathrm{SO}_{3}$ was identified after two-dimensional thin-layer electrophoresis (Huttner, 1984), proving the presence of tyrosine-sulphated proteins in this zone.

The electrophoretic distribution of ${ }^{35} \mathrm{~S}$-sulphated proteins released by uterine fragments into the media showed that progesterone had a distinct influence on the secreted proteins. In Group 3 and 5, the labelled proteins were more abundant in the region beyond $M_{\mathrm{r}} 100000$ than in Groups 2 and 4. The molecular weights of the major sulphated protein bands are shown in Fig. 3(b). Five sulphated protein bands of high molecular weight $\left(M_{r}, 260000,290000,320000,400000\right.$ and 500000 ) were particularly abundant in Group 5.

The tyrosine- $o-{ }^{35} \mathrm{SO}_{3}$ content of each gel slice was determined for the tissue-associated and secreted proteins. The individual bands of $M_{\mathrm{r}} 60000-220000$ were cut, extracted by pronase digestion and subjected to alkaline hydrolysis for tyrosine- ${ }^{-35} \mathrm{SO}_{3}$ determination. The content of tyrosine sulphate in each band, expressed as a percentage of total radioactivity before alkaline hydrolysis, ranged from 8 to $25 \%$. The bulk of the radioactivity recovered from these fractions was consequently located in the carbohydrate moieties. We did not find a protein that was labelled only on the tyrosine residues.

\section{Discussion}

A specific effect of oestrone sulphate on the endometrial cell surface has been reported by Alkhalaf et al. $(1987 \mathrm{a}, \mathrm{b})$. These modifications are related to variations in the secretory capacities of the cells. Consequently, it was of particular interest to study the action of oestrone sulphate on protein sulphation, especially on tyrosine residues, since this post-translational modification is considered to be a signal for protein secretion (Baeuerle \& Huttner, 1984).

The conditions of hormone treatments were as previously optimized in our laboratory (Alkhalaf et al., 1987a) according to the well-documented study of Milgrom et al. (1973). Oestradiol- $17 \beta$ or oestrone sulphate treatment of ovariectomized guinea-pigs did not increase the uptake of ${ }^{35} \mathrm{SO}_{4}$ into incubated fragments of uterus. In contrast, these hormonal treatments increased the sulphate incorporation into the cellular proteins. Consequently, the available precursor sulphate pool into tissue is not directly responsible for this increase. Takata \& Terayama (1979) and Isemura et al. (1981) have reported similar effects of oestradiol-17 $\beta$ on protein sulphation in rat and rabbit uteri. In the rabbit uterus, this effect of oestradiol-17 $\beta$ is suppressed by progesterone (Endo \& Yosizawa, 1980). In oestradiol-17 $\beta$-primed, but not in oestrone sulphateprimed guinea-pigs, progesterone significantly increased sulphate uptake. The most marked effect of progesterone in oestradiol-17 $\beta$ - and especially in oestrone sulphate-primed animals was the increase in the sulphation of proteins secreted by the uterus. It would seem that oestrone sulphate acts synergistically with progesterone to enhance preferentially the secretion of sulphated proteins. 
Tyrosine sulphate has been identified in the cellular and secreted proteins and oestradiol-17 $\beta$ treatment increased tyrosine sulphation in both types of uterine proteins. When progesterone was administered after oestradiol-17 $\beta$, the sulphation on tyrosine was essentially increased in the secreted proteins, indicating the role of progesterone on the extent of sulphation in the secreted proteins. Oestrone sulphate also induced an increase in tyrosine sulphation and its effect was equivalent to the effect of oestradiol- $17 \beta$ plus progesterone. Oestrone sulphate thus appears to be a potent steroid mimicking the action of progesterone. This point is corroborated by the fact that progesterone administered after oestrone sulphate slightly increased the level of tyrosine sulphation induced by oestrone sulphate alone.

Two mechanisms are able to induce a variation in protein sulphation: a variation in the biochemical process of sulphation or a variation in the pool of protein destined to be sulphated. A comparison of electrophoretic patterns of sulphated proteins showed that, in guinea-pig uterus, steroid hormones act on the extent of sulphation of proteins. In the tissue-associated proteins, an $M_{\mathrm{r}} 102000$ sulphated protein band was specifically found after oestradiol-17 $\beta+$ progesterone treatment whereas an $M_{\mathrm{r}} 125000$ sulphated protein band was found only after oestrone sulphate + progesterone. This protein was observed in vivo and may be a marker of the action of these two hormones.

We present here the first evidence of a specific action of oestrone sulphate on protein sulphation which is quite distinct from the action of oestradiol-17 $\beta$. Progesterone administered after oestradiol- $17 \beta$ or oestrone sulphate treatment markedly stimulated sulphate incorporation in high molecular weight proteins released into the medium. This effect was particularly pronounced after oestrone sulphate + progesterone treatment. It is well-known that, in responsive cells, oestradiol-17 $\beta$ and progesterone act synergistically, progesterone increasing the synthesis of secretory proteins. We observed the same synergistic action between oestrone sulphate and progesterone. In rat uteri, Takata \& Terayama (1979) reported that the synthesis and secretion of $M_{\mathrm{r}} 50000-100000$ sulphated components were stimulated by oestradiol-17 $\beta$ and inhibited by progesterone. Their study concerned the uterine response after $80 \mathrm{~min}$ incubation with the labelled sulphate. In guinea-pig uterus, the progesterone action on the sulphation of secreted proteins was significant after $18 \mathrm{~h}$ of incubation. Perhaps the early response of the uterus is different from the delayed response in relation to the sulphation of the secreted proteins. This point must be clarified.

Ovarian steroids induce the synthesis and secretion of specific uterine proteins, some of which have been identified, e.g. creatine kinase (Notides \& Gorski, 1966), uteroglobin (Beato \& Baier, 1975), uteroferrins (Roberts \& Bazer, 1980), prolactin (Heffner et al., 1986) and lactotransferrin (Pentecost \& Teng, 1987). Some of these proteins may be related to the sulphated proteins reported here. Anderson et al. (1986) described high molecular weight glycoproteins binding lectins and undergoing modifications at the time of implantation in the rabbit. The rabbit uterus contains a protein of $M_{\mathrm{r}} 135000$ which is secreted under progesterone action. In human endometrium, an $M_{\mathrm{r}}$ 130000 secreted glycoprotein has been characterized by Strinden \& Shapiro (1983) and a tissueassociated $M_{\mathrm{r}} 51000$ protein regulated by progesterone by Jacobelli et al. (1981). These proteins may be related to the $M_{\mathrm{r}} 131000$ and 51000 sulphated proteins found in this study. However, the relevant literature does not provide any information concerning the steroid action on the sulphation of guinea-pig uterine proteins.

As in numerous tissues for other species, tyrosine-sulphated proteins exist in the guinea-pig uterus but we have not characterized proteins sulphated only on tyrosine. It would appear that the uterine tyrosine-sulphated proteins of guinea-pigs were sulphated on both tyrosine residues and carbohydrate moieties. These proteins have already been described in other tissues (Huttner \& Baeuerle, 1988). However, we cannot exclude the possibility that proteins are only sulphated on tyrosine, masked by the bulk of sulphated glycoproteins. Only an analysis of sulphated proteins separated by class, for example after ion-exchange chromatography (Paulsson et al., 1985), will enable this point to be clarified. 
An oestrogenic action of oestrone sulphate on the guinea-pig uterus has been reported (Adessi et al., 1982; Moutaouakkil et al., 1984). It was thought that this effect was mediated by the hydrolysis of oestrone sulphate and the formation in the target tissue of unconjugated oestrone and oestradiol-17 $\beta$. In this hypothesis, the response of the tissue under oestrone sulphate stimulation would seem to be identical to the response obtained with oestradiol-17 $\beta$, which is the most potent biological oestrogen. In vivo and in vitro, there is a direct effect of oestrone sulphate on uterine epithelial cells (Alkhalaf et al., 1987a), which is different from the action of oestradiol-17 $\beta$. In the present study, the action of oestrone sulphate on sulphate incorporation into carbohydrate moieties and tyrosine residues does not mimic the action of oestradiol-17 $\beta$. Its most potent action appears to be on the sulphation of secreted proteins. In some ways, this effect is identical to the action of progesterone on oestradiol-17 $\beta$-primed animals. However, oestrone sulphate induces the specific sulphation of proteins different from those observed after oestradiol-17 $\beta$ plus progesterone treatment.

In conclusion, we suggest that oestrone sulphate is a potent biologically active hormone in the guinea-pig uterus.

We thank Mrs M. David for typing the manuscript and Mr M. J. Carew and Ms M. Gill for correcting the English text.

\section{References}

Adessi, G.L., Nhuan, T.Q. \& Vingler, P. (1982) In vivo and in vitro metabolism of estrone and estradiol- $17 \beta$ and their 3-sulphates in pregnant female guinea-pigs: a plausible prehormone role of estrogen sulphates in the maternal uterus. J. Steroid Biochem. 16, 107-116.

Alkhalaf, M., Chaminadas, G., Propper, A.Y. \& Adessi, G.L. (1987a) Compared effects of oestrogens and oestrone sulphate on the epithelial cell surface of guinea-pig endometrium (in vivo and in vitro studies). Expl Clin. Endocrinol. 89, 201-210.

Alkhalaf, M., Chaminadas, G., Propper, A.Y. \& Adessi, G.L. (1987b) Hormones and anti-hormones effects on cultured guinea-pig uterine epithelial cell surface. In Cell Biology, Vol. 12, pp. 101-109. Eds E. Wagner, H. Greppin \& B. Millet. Springer-Verlag, Berlin.

Anderson, T.L., Olson, G.E. \& Hoffman, L.H. (1986) Stage-specific alterations in the apical membrane glycoproteins of endometrial epithelial cells related to implantation in rabbits. Biol. Reprod. 34, 701-720.

Baeuerle, P.A. \& Huttner, W.B. (1984) Inhibition of $\mathrm{N}$-glycosylation induces tyrosine sulphation of hybridoma immunoglobulin. EMBO J/3, 2209-2215.

Beato, M. \& Baier, R. (1975) Binding of progesterone to the proteins of the uterine luminal fluid. Identification of uteroglobin as the binding protein. Biochim. Biophys. Acta 392, 346-356.

Brooks, S.C., Leithauser, G., De Locker, W.C. \& De Wever, F. (1969) In vitro stimulation of protein synthesis in uterine microsomal supernatant by estrone sulfate. Endocrinology 84, 901-907.

Chamberlain, J.P. (1979) Fluorographic detection of radioactivity in polyacrylamide gels with the watersoluble fluor sodium salicylate. Analyt. Biochem. 98, 132-135.

Chaminadas, G., Rémy-Martin, J.P., Alkhalaf, M., Propper, A.Y. \& Adessi, G.L. (1989) Effect of progesterone on protein synthesis and secretion by cultured epithelial cells from guinea-pig endometrium. Cell Tissue Res. 257, 129-136.

Dogson, K.S., Rose, F.A. \& Tudball, N. (1959) Studies on sulphatases. Biochem. J. 71, 10-15.

Dutt, A., Tang, J.P., Welply, J.K. \& Carson, D.D. (1986) Regulation of $\mathrm{N}$-linked glycoprotein assembly in uteri by steroid hormones. Endocrinology 118, 661-673.

Endo, M. \& Yosizawa, Z. (1980) Progesterone effect on the biosynthesis of glycoconjugates, specifically of sulphated glycoprotein, in the endometrium of rabbit uterus. Tohok u J. exp. Med. 132, 147-152.

Frazier, W. \& Glaser, L. (1979) Surface components and cell recognition. Ann. Rev. Biochem. 49, 49I-523.

Green, E.D., Gruenebanm, J., Bielinska, M., Baenziger, J.U. \& Boime, I. (1984) Sulfation of lutropin oligosaccharides with a cell-free system. Proc. natn. Acad. Sci. USA 81, 5320-5324.

Heffner, L.J., Iddenden, D.A. \& Lyttle, C.R. (1986) Electrophoretic analysis of secreted human endometrial proteins: identification and characterization of luteal phase prolactin. J. clin. Endocr. Metab. 40, $1288-1295$.

Hille, A., Rosa, P. \& Huttner, W.B. (1984) Tyrosine sulfation: a post-translational modification of proteins destined for secretion? FEBS Lett. 177, 129-134.

Huttner, W.B. (1984) Determination and occurrence of tyrosine-O-sulfate in proteins. Methods Enzymol. 107, 200-223.

Huttner, W.B. \& Baeuerle, P.A. (1988) Protein sulfation on tyrosine. In Modern Cell Biology, Vol. 6, pp. 97-140. Ed. B. H. Satir. Alan R. Liss. Inc., New York.

Isemura, M., Munakata, H. \& Yosizawa, Z. (1981) Hormonal effects on the sulfation of sulfated glycoproteins in a particulate fraction of the endometrium of rabbit uterus. J. Biochem., Tokyo 89, 1815-1819. 
Jacobelli, S., Marchetti, P., Bartoccioni, E., Matoli, V., Scambia, G. \& Kaye, A. (1981) Steroid induced proteins in human endometrium. Molec. cell. Endocrinol. 23, 321-326.

Joshi, S.G. \& Ebert, K.M. (1976) Effects of progesterone on labeling of soluble proteins and glycoproteins in rabbit endometrium. Fert. Steril. 27, 730-739.

Laemmli, U.K. (1970) Cleavage of structural proteins during the assembly of the head of bacteriophage T4. Nature, Lond. 227, 680-685.

Larsen, B.R. \& West, F.G. (1981) A method for quantitative amino acid analysis using precolumn $\mathrm{O}$ phthalaldehyde derivatization and high performance liquid chromatography. J. Chromatogr. Sci. 1, 259-265.

Lowry, O.H., Rosebrough, M.J., Farr, A.L. \& Randall, R. (1951) Protein determination with the Folin phenol reagent. J. biol. Chem. 193, 265-275.

Milgrom, E., Thi, L., Atger, M. \& Baulieu, E.E. (1973) Mechanisms regulating the concentration and the conformation of progesterone receptor(s) in the uterus. J. biol. Chem. 25, 6366-6374.

Moutaouakkil, M., Prost, O., Dahan, N. \& Adessi, G.L. (1984) Estrone and dehydroepiandrosterone sulfatase activities in guinea-pig uterus and liver: estrogenic effect of estrone sulphate. J. Steroid Biochem. 21, 321-328.

Notides, A. \& Gorski, J. (1966) Estrogen-induced synthesis of a specific uterine protein. Proc. natn. Acad. Sci. USA 56, 230-237.

Palade, G.E. (1975) Intracellular aspects of the process of protein secretion. Science, $N Y 189,347-358$.

Pasqualini, J.R., Lanzone, A., Tahri-Joutei, A. \& NGuyen, B.L. (1982) Effects of seven different estrogen-sulfates on uterine growth and progesterone receptor in the foetal uterus of guinea-pig after administration to the mother. Acta endocr., Copenh. 101, 630-635.

Paulsson, M., Dziadek, M., Suchaned, C., Huttner, W.B. \& Timpl, R. (1985) Nature of sulphated macromolecules in mouse Reichert's membrane. Biochem. $J$. 231, 571-579.

Pentecost, B.T. \& Teng, C.T. (1987) Lactotransferrin is the major estrogen inducible protein of mouse uterine secretions. J. biol. Chem. 262, 10134-10139.

Roberts, R.M. \& Bazer, F.W. (1980) The properties, function and hormonal control of synthesis of uteroferrin, the purple protein of the pig uterus. In Steroid-Induced Uterine Proteins, pp. 133-149. Ed. M. Beato. Elsevier-North-Holland, Amsterdam.

Rossier, G. \& Pierrepoint, C.G. (1974) Oestrogen metabolism in sheep myometrium. J. Reprod. Fert. 37, $43-49$.

Strinden, S.T. \& Shapiro, S.S. (1983) Progesteronealtered secretory protein from cultured human endometrium. Endocrinology 112, 862-870.

Takata, K. \& Terayama, H. (1977) Hormonal effect on glycosaminoglycans and glycoproteins in uteri of ovariectomized rats. Biochim. Biophys. Acta 500, 333-343.

Takata, K. \& Terayama, H. (1979) Estrogen dependent and progesterone-arrested synthesis and secretion of sulfated glycoproteins in luminal epithelial of rat uteri. Biochim. Biophys. Acta 586, 594-607.

Tan, K.K. (1978) Assay of proteins by Lowry's method on samples containing 2-mercaptoethanol. Analyt. Biochem. 96, 327-331.

Tseng, L., Stolee, A. \& Gurpide, E. (1972) Quantitative studies on the uptake and metabolism of oestrogens and progesterone by human endometrium. Endocrinology 90, 390-404. 